\title{
Ovarian Steroid Hormone Secretion by Human Granulosa Cells After Supplementation of Sambucus nigra L. Extract
}

\author{
Simona BALDOVSKA ${ }^{1}$, Shubhadeep ROYCHOUDHURY ${ }^{2}$, Marek BANDIK ${ }^{3}$, Michal \\ MIHAL $^{3}$, Erika MNAHONCAKOVA ${ }^{4}$, Julius ARVAY ${ }^{5}$, Ales PAVLIK ${ }^{6}$, Petr SLAMA ${ }^{6}$, \\ Adriana KOLESAROVA ${ }^{3}$
}

${ }^{1}$ AgroBioTech Research Centre, Slovak University of Agriculture in Nitra, Nitra, Slovak Republic, ${ }^{2}$ Department of Life Science and Bioinformatics, Assam University, Silchar, India, ${ }^{3}$ Department of Animal Physiology, Faculty of Biotechnology and Food Sciences, Slovak University of Agriculture in Nitra, Nitra, Slovak Republic, ${ }^{4}$ Botanical Garden of Slovak University of Agriculture in Nitra, Nitra, Slovak Republic, ${ }^{5}$ Department of Chemistry, Faculty of Biotechnology and Food Sciences, Slovak University of Agriculture in Nitra, Nitra, Slovak Republic, ${ }^{6}$ Department of Animal Morphology, Physiology and Genetics, Faculty of AgriSciences, Mendel University in Brno, Brno, Czech Republic

Received March 15, 2021

Accepted July 29, 2021

Epub Ahead of Print September 10, 2021

\section{Summary}

Beneficial effects of Sambucus nigra L. (black elder) as a traditional medicine have been associated with the phytoconstituents including polyphenols, terpenes and lectins. Various antioxidant rich natural products have also been implicated with improvement of reproductive health and fertility, however, the effect of Sambucus nigra on the ovarian cell functions has not been investigated yet. The objectives of the present study were to screen the polyphenols in the elderflower and elderberry extracts, and to examine the secretion activity of steroid hormones $17 \beta$-estradiol and progesterone by human ovarian granulosa cells HGL5 after supplementation of the extracts at a concentration range of 12.5 to $100 \mu \mathrm{g} \cdot \mathrm{ml}^{-1}$. Qualitative as well as quantitative screening of polyphenols by high-performance liquid chromatography with diode-array detector (HPLC-DAD) analysis revealed rutin to be the most abundant polyphenol in both elderflower and elderberry extracts. In culture, neither elderflower nor elderberry extract caused any significant impact $(p>0.05)$ in cell viability as studied by AlamarBlue assay in comparison to control. However, a dosedependent stimulation of $17 \beta$-estradiol release was detected by ELISA after supplementation of elderflower (at $50 \mu \mathrm{g} \cdot \mathrm{ml}^{-1}$; $\mathrm{p}<0.01$ ) and elderberry (at $100 \mu \mathrm{g} \cdot \mathrm{ml}^{-1} ; \mathrm{p}<0.05$ ) extracts at higher doses used in the study. On the other hand, both elderflower and elderberry extracts stimulated the secretion of progesterone by HGL5 cells at a lower dose $\left(12.5 \mu \mathrm{g} \cdot \mathrm{ml}^{-1}\right.$; $\mathrm{p}<0.05)$, as compared to control. Therefore, elderflower and elderberry extracts may have the potential to regulate steroidogenesis in ovarian cells.

\section{Key words}

Black elder • HGL5 • Ovarian steroidogenesis • 17ß-estradiol • Progesterone

\section{Corresponding author}

A. Kolesárová, Department of Animal Physiology, Faculty of Biotechnology and Food Sciences, Slovak University of Agriculture in Nitra, Tr. A. Hlinku 2, 94976 Nitra, Slovak Republic. E-mail: adriana.kolesarova@uniag.sk

\section{Introduction}

Sambucus nigra L. (black elder) is used as a traditional herbal medicine across various regions of Europe. In recent times, it has found widespread use in dietary supplements as natural health products including extracts, juices or syrups to boost immunity. Sambucus nigra L. represents a possible dietary adjunct for the treatment of a number of diseases including diabetes mellitus (Ciocoiu et al. 2009), upper respiratory tract 
infections (Knudsen and Kaack 2015), human pathogenic bacteria (Gram-positive Streptococcus pyogenes and group C and G Streptococci, and Gram-negative Branhamella catarrhalis) and human pathogenic influenza virus infection (Krawitz et al. 2011), cold, flu (Mahboubi 2020), other chronic metabolic and cardiovascular illnesses (Ciocoiu et al. 2009). Beneficial effects on blood pressure, glycemia reduction, lipemia reduction, immune system stimulation, antitumour potential (Ciocoiu et al. 2009, Sidor and GramzaMichałowska 2015) have been associated its antioxidant phytoconstituents such as polyphenols (anthocyanins, flavonols, phenolic acids and proanthocyanidins), terpenes and lectins (Sidor and Gramza-Michałowska 2015). Various antioxidant rich natural products have also been implicated with improvement reproductive health and fertility. Phytoestrogens are biologically active substances known to exert hormonal effects. Due to the similarity of chemical structure with steroid hormone $17 \beta$-estradiol, many of them can manipulate steroidogenesis and endogenous hormone levels by interfering with the enzymes needed for steroid biosynthesis (Patisaul and Jefferson 2010). Studies in humans, animal models, and cell lines suggest that dietary phytoestrogens with biological effects including estrogenic potency can play important beneficial roles in reproductive processes, hormone-dependent cancers, prevention of menopausal symptoms and osteoporosis, as well as the risk of heart diseases (Desmawati and Sulastri 2019). However, the effect of Sambucus nigra L. on the ovarian cell functions has not been investigated yet.

The elderflower and elderberry extracts are natural mixtures of substances, each of which can have different biological effects. The effects observed in the study are the results of the mixture action. The objectives of the present study were to screen the polyphenols in the elderflower and elderberry extracts, and to examine the secretion activity of steroid hormones $17 \beta$-estradiol and progesterone by human ovarian granulosa cells HGL5 after addition of the extracts at a concentration range of 12.5 to $100 \mu \mathrm{g} \cdot \mathrm{ml}^{-1}$ of elderflower and elderberry extracts.

\section{Methods}

Preparation of extracts and HPLC-DAD screening of polyphenols

Elderflowers and elderberries were collected from the Botanical Garden of the Slovak University of
Agriculture in Nitra, Nitra, Slovak Republic (Fig. 1). Extraction of $2 \mathrm{~g}$ dried and grounded plant material was done in $20 \mathrm{ml} 80 \%$ ethanol (v/v) at the room temperature for $4 \mathrm{~h}$ by horizontal shaker Unimax 2010 (Heidolph Instruments, GmbH, Germany). Prior to HPLC analyses, the extracts were filtered through syringe PTFE filters $(0.45 \mu \mathrm{m}, 25 \mathrm{~mm})$ (Agilent Technologies, Waldbronn, Germany) and stored in a refrigerator at $4{ }^{\circ} \mathrm{C}$. All phenolic compounds were determined by highperformance liquid chromatography system with diode array detector (HPLC-DAD) instrumentation Agilent Infinity 1260 (Agilent Technologies, Waldbronn, Germany) in the crude extracts. All analytical standards (chlorogenic acid, 4-OH-benzoic acid, trans-caffeic acid, trans-p-coumaric acid, trans-ferulic acid, rutin, myricetin, resveratrol, apigenin, genistein, and kaempferol), acetonitrile (HPLC gradient grade), methanol (HPLC grade), and phosphoric acid (ACS grade) were purchased from Sigma Aldrich (Sigma-Aldrich Chemie $\mathrm{GmbH}$, Steinheim, Germany). Double deionized water $\left(\mathrm{ddH}_{2} \mathrm{O}\right)$ was treated $\left(18.2 \mathrm{M} \Omega \mathrm{cm}^{-1}\right)$ in a Simplicity 185 purification system (Millipore SAS, Molsheim, France). All analyses were performed on a Cortecs column (4.6 mm $\times 150 \mathrm{~mm} \times 2.7 \mu \mathrm{m}) \quad$ (Waters, Massachusetts, USA). The mobile phases consisted of $0.1 \% \mathrm{H}_{3} \mathrm{PO}_{4}$ in $\mathrm{ddH}_{2} \mathrm{O}(\mathrm{v} / \mathrm{v})(\mathrm{A})$ and acetonitrile (B). The mobile phase flow was $0.6 \mathrm{ml} \mathrm{min}{ }^{-1}$ and the sample injection was $5 \mu 1$. The column thermostat was set to $30^{\circ} \mathrm{C}$ and the samples were kept at $6^{\circ} \mathrm{C}$ in the sampler manager. The detection wavelength was set at $265 \mathrm{~nm}, 320 \mathrm{~nm}$, and $372 \mathrm{~nm}$. The compounds were identified by comparing with standards of each identified compound using retention time, the absorbance spectrum profile, and also by running the samples after the addition of pure standards (Gabriele et al. 2018).

\section{Cell culture and treatment}

Elderflower and elderberry extracts were dissolved in a culture medium and diluted to the desired concentrations prior to experiments. Immortalized human ovarian granulosa cell line HGL5 (ABM ${ }^{\circledR}, \mathrm{BC}$, Canada) was cultured in Dulbecco's modified Eagle medium (Sigma-Aldrich, MO, USA) supplemented with $10 \%$ fetal bovine serum (Sigma-Aldrich, MO, USA), $1 \%$ antibiotics/antimycotic solution (Invitrogen, CA, USA). The initial concentrations of cells before setting up the culture ranged from 104 to 105 cells per ml. Cells were cultured in plates without (control group) or with elderflower or elderberry extracts at concentrations of 

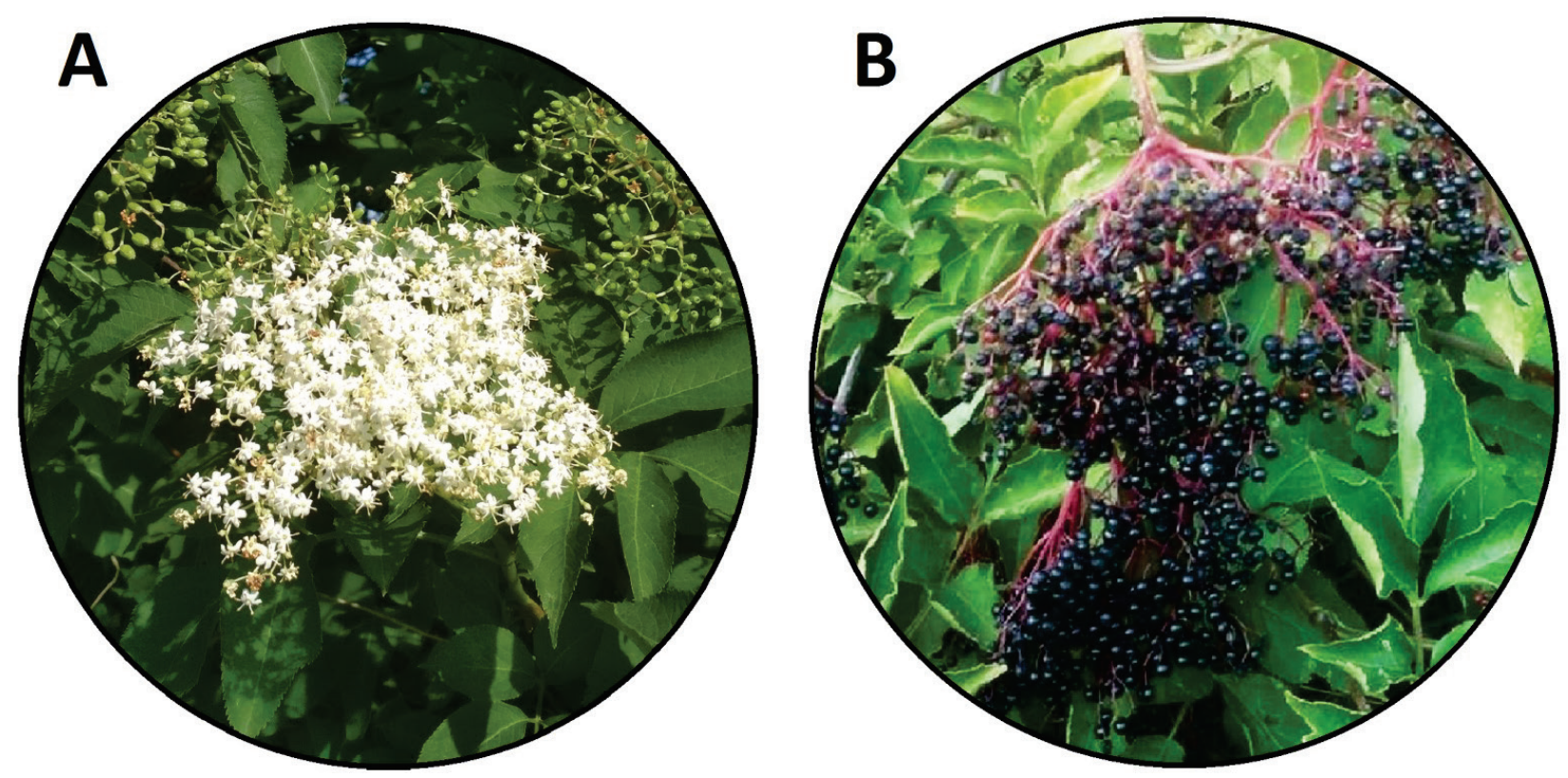

Fig. 1. Elderflowers (A) and elderberries (B) harvested for the preparation of ethanolic extracts.

$12.5,25,50$, and $100 \mu \mathrm{g} \cdot \mathrm{ml}^{-1}$ of extracts for $24 \mathrm{~h}$. As a positive control $80 \%$ ethanol in an amount corresponding to the highest used concentration of the respective extracts was used and the final ethanol concentration in well was less than $0.1 \%$. All the procedures followed were in accordance with institutional guidelines (Baldovská et al. 2020).

\section{Cell viability}

Cell viability was examined using AlamarBlue (BioSource International, Nivelles, Belgium) assay (Michalcova et al. 2019). Cells $\left(1.5 \times 10^{4}\right.$ cells per $\left.\mathrm{ml}\right)$ were re-seeded in a 96-well plate (Grainer, Germany) and grown in culture for $24 \mathrm{~h}$ without (control group) or with elderflower/elderberry extracts $(12.5,25,50$, and $100 \mu \mathrm{g} . \mathrm{ml}^{-1}$ ), or with $80 \%$ ethanol in an amount corresponding to the highest used concentration of the respective extracts (as positive control). Resazurin reduction (oxidized indigo blue state into the reduced pink state) was measured by recording the absorbance at 560 and $590 \mathrm{~nm}$ using a microplate reader (Multiskan FC, ThermoFisher Scientific, Finland) and expressed as percentage.

\section{ELISA}

Concentrations of secreted $17 \beta$-estradiol and progesterone were determined in duplicate in the incubation medium by ELISA as described previously (Roychoudhury et al. 2018, Kolesarova et al. 2019, Baldovská et al. 2020) spectrophotometrically using ELISA kit (NOVATEC, Dietzenbach, Germany) according to the manufacturer's instructions. All ELISA assays were validated for use in samples of culture medium. Cells were re-seeded in a 24-well culture plate (Grainer, Germany) at a density of $1 \times 10^{5}$ cells per $\mathrm{ml}$. For $17 \beta$-estradiol, intra- and inter-assay coefficients of variation did not exceed 9 and $10 \%$, respectively. For progesterone, intra- and inter-assay coefficients of variation did not exceed 4 and $9.3 \%$, respectively. The sensitiveness was $8.68 \mathrm{pg} . \mathrm{ml}^{-1}$ for $17 \beta$-estradiol and $0.05 \mathrm{ng} \cdot \mathrm{ml}^{-1}$ for progesterone.

\section{Statistical analysis}

Three samples in one group in one experiment was used. Analyses were performed in at least three independent experiments with replicates per experiment. All data were expressed as the mean \pm standard error of the mean (SEM). Statistical analysis was carried out using the GraphPad Prism 5 program (version 3.02 for Windows; GraphPad Software, CA, USA). One-way analysis of variance (ANOVA) along with Dunnett's test was performed as appropriate to determine the statistical significance of differences of the data. The statistical significance was set at probability values of $\mathrm{p}<0.05$.

\section{Results}

HPLC-DAD screening of polyphenolic compounds revealed rutin $(12913.00 \pm 22.35$ vs. $\left.4599.00 \pm 81.63 \mathrm{mg} . \mathrm{kg}^{-1}\right)$ and chlorogenic acid $\left(5555.00 \pm 20.08\right.$ vs. $\left.810.60 \pm 14.20 \mathrm{mg} \cdot \mathrm{kg}^{-1}\right)$ to be the most abundant polyphenols in both elderflower and elderberry 
extracts, respectively (Table 1). Polyphenolic constituents were notably higher in elderflower extract in comparison to that of elderberry extract and the concentrations of individual polyphenols also varied greatly between elderflower and elderberry extracts. Apigenin $\left(1352.00 \pm 3.01 \mathrm{mg} \cdot \mathrm{kg}^{-1}\right)$, resveratrol $\left(768.30 \pm 2.32 \mathrm{mg} \cdot \mathrm{kg}^{-1}\right)$, kaempferol $\left(452.60 \pm 163.60 \mathrm{mg} \cdot \mathrm{kg}^{-1}\right)$, trans-ferulic acid (314.30 $\left.\pm 1.40 \mathrm{mg} \cdot \mathrm{kg}^{-1}\right)$, myricetin $\left(109.30 \pm 1.88 \mathrm{mg} \cdot \mathrm{kg}^{-1}\right)$,
4-OH-benzoic acid $\left(69.44 \pm 0.37 \mathrm{mg} . \mathrm{kg}^{-1}\right), \quad$ trans-caffeic acid $\quad\left(62.75 \pm 0.28 \mathrm{mg} . \mathrm{kg}^{-1}\right), \quad$ trans-p-coumaric acid (49.70 $\left.\pm 1.16 \mathrm{mg} . \mathrm{kg}^{-1}\right)$ and genistein $\left(17.48 \pm 0.088 \mathrm{mg} . \mathrm{kg}^{-1}\right)$ were the other polyphenolic compounds present in elderflower extract whereas elderberry extract contained trans-ferulic acid $\left(245.20 \pm 5.21{\left.\mathrm{mg} . \mathrm{kg}^{-1}\right), 4-\mathrm{OH}-\text { benzoic }}^{-1}\right.$ acid $\quad\left(35.70 \pm 0.94 \mathrm{mg} . \mathrm{kg}^{-1}\right) \quad$ and genistein $\left(29.12 \pm 0.11 \mathrm{mg} \cdot \mathrm{kg}^{-1}\right)$.

Table 1. Screening of the polyphenolic contents in elderberry extracts.

\begin{tabular}{|c|c|c|}
\hline \multirow{2}{*}{$\begin{array}{l}\text { Polyphenols } \\
\text { (average amount in } \mathrm{mg} \cdot \mathrm{kg}^{-1} \text { ) }\end{array}$} & \multicolumn{2}{|c|}{$\begin{array}{c}\text { Elderberry } \\
\text { (Sambucus nigra L.) }\end{array}$} \\
\hline & Flowers & Berries \\
\hline Chlorogenic acid & $5555.00 \pm 20.08$ & $810.60 \pm 14.20$ \\
\hline 4-OH-benzoic acid & $69.44 \pm 0.37$ & $35.70 \pm 0.94$ \\
\hline trans-Caffeic acid & $62.75 \pm 0.28$ & $\leq \mathrm{LOD}$ \\
\hline trans-p-Coumaric acid & $49.70 \pm 1.16$ & $\leq \mathrm{LOD}$ \\
\hline trans-Ferulic acid & $314.30 \pm 1.40$ & $245.20 \pm 5.21$ \\
\hline Rutin & $12913.00 \pm 22.35$ & $4599.00 \pm 81.63$ \\
\hline Myricetin & $109.30 \pm 1.88$ & $\leq \mathrm{LOD}$ \\
\hline Resveratrol & $768.30 \pm 2.32$ & $\leq \mathrm{LOD}$ \\
\hline Apigenin & $1352.00 \pm 3.01$ & $\leq \mathrm{LOD}$ \\
\hline Genistein & $17.48 \pm 0.088$ & $29.12 \pm 0.11$ \\
\hline Kaempferol & $452.60 \pm 163.60$ & $\leq \mathrm{LOD}$ \\
\hline
\end{tabular}

* LOD - limit of detection, \pm standard error.

In culture, HGL5 cells did not lose viability after supplementation of either elderflower extract or elderberry extract at all the concentrations used in the study, as compared with control (Fig. 2). However, supplementation of Sambucus nigra L. extract stimulated the release of steroid hormones 17 $\beta$-estradiol and progesterone depending on the concentrations used. At higher concentrations used in the present study, a significantly higher secretion of $17 \beta$-estradiol was observed after the addition of both elderflower (at $50 \mu \mathrm{g} \cdot \mathrm{ml}^{-1} ; \mathrm{p}<0.01$ ) and elderberry (at $100 \mu \mathrm{g} \cdot \mathrm{ml}^{-1}$; $\mathrm{p}<0.05$ ) extracts, as compared to control (Fig. 3). On the other hand, an increase in progesterone release was noted after administration of a lower dose of $12.5 \mu \mathrm{g} . \mathrm{ml}^{-1}$ elderflower as well as elderberry extracts $(p<0.05)$, as compared to control (Fig. 4).

\section{Discussion}

Granulosa cells forms the main cell type that is involved in the process of ovarian steroidogenesis and folliculogenesis (Ai et al. 2019). Their principal secretory products include steroid hormones $17 \beta$-estradiol and progesterone which are involved in multiple physiological processes by acting on various tissues and they play an important role in the modulation of ovarian functions and female fertility (Kolesárová et al. 2015). Decreased gonadal steroid production causes several physiological changes that result in menopausal symptoms and the development of osteoporosis, too (Lecomte et al. 2017). Estradiol is considered a marker of meiotic arrest of oocytes (Dode and Graves 2003) while progesterone is a marker of ovarian follicle luteinization (Kadasi et al. 2014). Estradiol and its receptors are necessary for the control and regulation of many biological responses that strongly affect several aspects of physiology, such as risk factors for the initiation and progression of hormone-related cancers including ovarian and breast cancer (Deroo and Korach 2006). Progesterone is essential for normal ovarian cycles and contributes to the regulation of ovarian follicular development and remodeling (Arnhold et al. 2009, Hagan et al. 2008, 


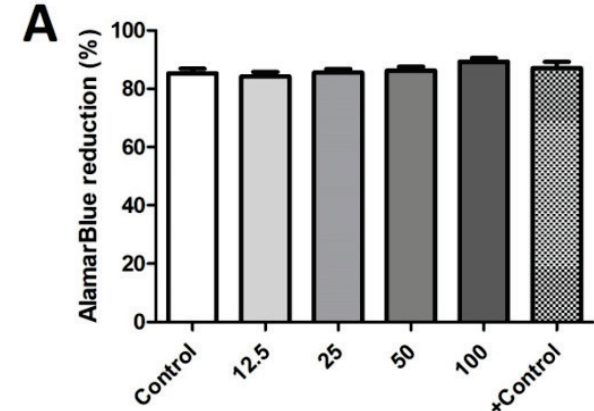

Elderflower extract $\left(\mu \mathrm{g} \cdot \mathrm{ml}^{-1}\right)$

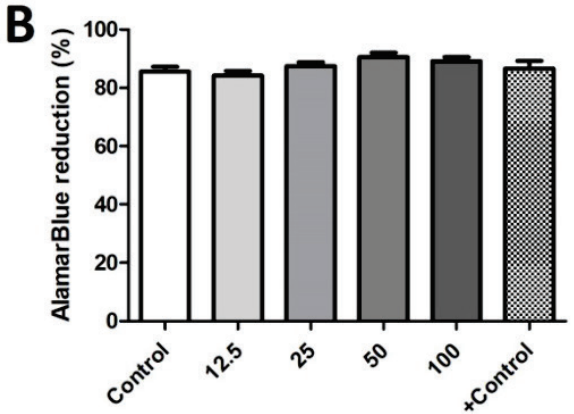

Elderberry extract $\left(\mu \mathrm{g} \cdot \mathrm{ml}^{-1}\right)$

Fig. 2. The cell viability was evaluated by using AlamarBlue assay. The change in the reduced state was measured spectrophotometrically. The effect of elderberry extract from flowers (A) and berries (B) on the viability of human ovarian granulosa cells HGL5. Control represents cells without treatment, in experimental groups elderflower and elderberry extracts were administered at $12.5,25,50$, and $100 \mu \mathrm{g} \cdot \mathrm{ml}^{-1}$ for $24 \mathrm{~h}$. Cells treated with ethanol in an amount corresponding to the highest used concentration of extract were used as positive controls (+ Control). The significance of differences between the groups were evaluated by one-way ANOVA followed by Dunnett's multiple comparison test. The data are expressed as means \pm SEM.

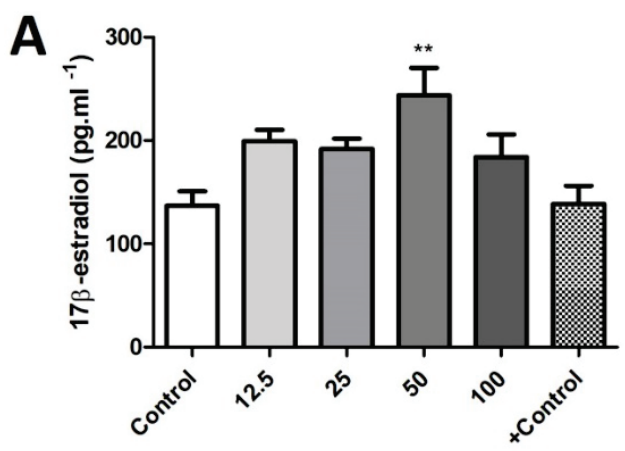

Elderflower extract $\left(\mu \mathrm{g} \cdot \mathrm{ml}^{-1}\right)$

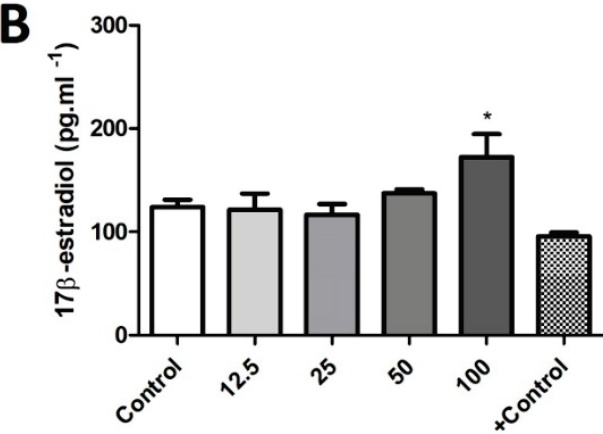

Elderberry extract $\left(\mu \mathrm{g} \cdot \mathrm{ml}^{-1}\right)$

Fig. 3. The quantitative determination of $17 \beta$-estradiol concentration in culture supernatants was performed by ELISA and measured spectrophotometrically. The effect of elderberry extract from flowers (A) and berries (B) on the release of $17 \beta$-estradiol by human ovarian granulosa cells HGL5. Control represents culture medium without treatment, in experimental groups elderflower and elderberry extracts were administered at $12.5,25,50$, and $100 \mu \mathrm{g} \cdot \mathrm{ml}^{-1}$ for $24 \mathrm{~h}$. Cells treated with ethanol in an amount corresponding to the highest used concentration of extract were used as positive controls (+Control). The significance of differences $*(p<0.05), * *(p<0.01)$ between the groups were evaluated by one-way ANOVA followed by Dunnett's multiple comparison test. The data are expressed as means \pm SEM.

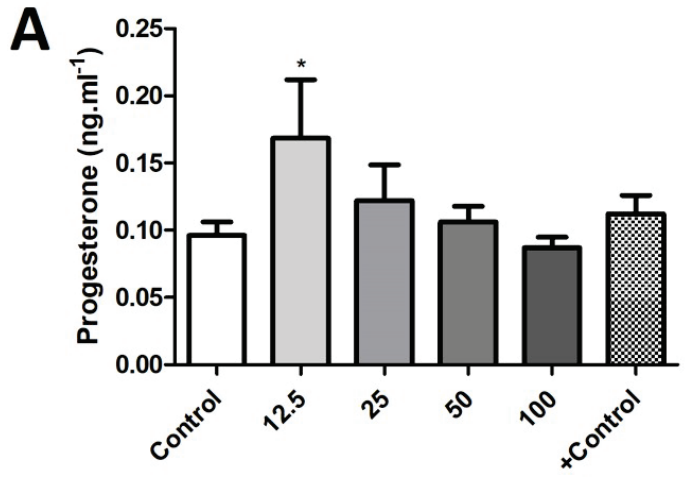

Elderflower extract $\left(\mu \mathrm{g} \cdot \mathrm{ml}^{-1}\right)$

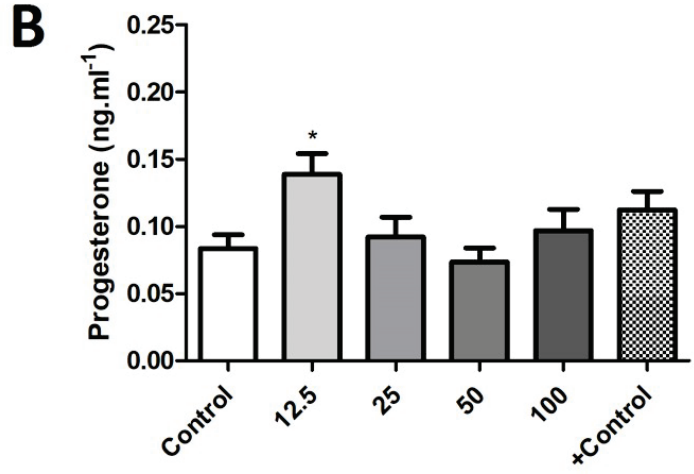

Elderberry extract $\left(\mu \mathrm{g} \cdot \mathrm{ml}^{-1}\right)$

Fig. 4. The quantitave determination of progesterone concentration in culture supernatants was performed by ELISA and measured spectrophotometrically. The effect of elderberry extract from flowers (A) and berries (B) on the release of progesterone by human ovarian granulosa cells HGL5. Control represents culture medium without treatment, in experimental groups elderflower and elderberry extracts were administered at $12.5,25,50$, and $100 \mu \mathrm{g} \cdot \mathrm{ml}^{-1}$ for $24 \mathrm{~h}$. Cells treated with ethanol in an amount corresponding to the highest used concentration of extract were used as positive controls (+Control). The significance of differences $*(p<0.01)$ between the groups were evaluated by one-way ANOVA followed by Dunnett's multiple comparison test. The data are expressed as means \pm SEM. 
Mahajan 2008). HGL5 is an immortalized cell line derived from primary hGL cells after transformation with the E6 and E7 regions of human papillomavirus 16, and it forms an attractive model for investigating the mechanisms relating to the steroid biosynthesis as well as other pathways of hGL function (Rainey et al. 1994, Havelock and Rainey 2004, Bouraki et al. 2012). To our knowledge, this is the first report that has looked into the impact of Sambucus nigra L. extract on the viability of ovarian granulosa cells, and the secretion of steroid hormones $17 \beta$-estradiol and progesterone in vitro.

Elderberry species have received significant attention especially for their antioxidant capacity for food applications as a natural conservative, functional food, or food supplement (Marisa Ribeiro et al. 2020). Elderberry (Sambucus nigra) is used in the treatment of many diseases due to antioxidant, anticancer, immune stimulating, antiallergic, antiviral and antibacterial properties (Młynarczyk et al. 2018, Oniszczuk et al. 2016). Recently, the benefits of Sambucus nigra L. and more particularly its bioactive compounds have been reported by a number of researchers (Sidor and GramzaMichałowska 2015, Młynarczyk et al. 2018, Mota et al. 2020, Marisa Ribeiro et al. 2020).

Sambucus nigra flowers and berries are rich in polyphenolic phytocompounds with important bioactivities. HPLC-DAD screening of polyphenolic compounds showed rutin and chlorogenic acid to be the most abundant polyphenols in both elderflower and elderberry extracts used in the study. Kaltsa et al. (2020) reported, that the richest elderberry flowers extract was produced with a $10 \mathrm{~min}$ ultrasonication pretreatment and then stirred-tank extraction under optimized conditions, at $80{ }^{\circ} \mathrm{C}$, for $150 \mathrm{~min}$. Data from the study on elderberry extract from Sambucus nigra flowers collected from Greece (the area of Neohori) were in line with results obtained in our study, reporting dominant contents for rutin, a di-p-coumaroylquic acid and chlorogenic acid by using liquid chromatography-mass spectrometry analysis (Kaltsa et al. 2020). The elderflower and elderberry extracts are natural mixtures of substances and can possess different biological effects. Therefore, the effects of the mixture action were observed in this study. As examined by AlamarBlue assay, supplementation of Sambucus nigra L. extract did not cause cytotoxicity and the viability of HGL5 cells was found intact at all the concentrations of elderflower and elderberry extracts used in the study. On the other hand, Chen et al. (2013) reported a negative correlation between elderflower and elderberry extracts (at 50-1600 $\mu \mathrm{g} \cdot \mathrm{ml}^{-1}$ for baby hamster kidney fibroblast cells BHK-21; and at 50-800 $\mu \mathrm{g} \cdot \mathrm{ml}^{-1}$ for kidney epithelial cells VERO), by using the Alamar Blue assay (Castillo-Maldonado et al. 2017). However, dwarf elder (Sambucus ebulus) extract at a concentration range of $5-1500 \mu \mathrm{g} \cdot \mathrm{ml}^{-1}$ was able to reduce the viability of cancer cell lines HepG2 and CT26 when examined by MTT assay (Saravi et al. 2013). Isoflavone rutin (the most abundant polyphenol in elderflower as well as elderberry extracts as detected in the present study) also inhibited the viability of human neuroblastoma cells LAN-5 (Chen et al. 2013). Rutin supplementation at $10 \mu \mathrm{g} . \mathrm{ml}^{-1}$ was also reported to decrease the viability of cultured porcine ovarian granulosa cells (Sirotkin et al. 2021).

Schroder and colleagues (2016) studied the effect of elderflower extract at 5, 50 and $100 \mu \mathrm{g} \cdot \mathrm{ml}^{-1}$ doses on chorion carcinoma cell lines JEG-3 and BeWo as well as the breast carcinoma cell line MCF7. Estradiol production was found to be inhibited in all cells, however, in JEG-3 cells an upregulation of estrogen receptor $\alpha(E R \alpha)$ was seen whereas in MCF7 cells ER $\alpha$ was downregulated and progesterone receptor was upregulated after supplementation of elderflower extract (Schroder et al. 2016). A previous study reported, that Sambucus nigra agglutinin can reduce viability and mitochondrial activity and induce apoptosis in ovarian cancer cells. Sambucus nigra agglutinin activate intracellular signaling pathways of AKT and ERK1/2, which promotes dephosphorylation of dynamin-related protein-1 (Drp-1) inducing fragmentation of mitochondrial membrane resulted in mitochondrial outer membrane permeabilization. Following generation of reactive oxygen species (ROS) and cytochrome-c release into the cytosol and may result in apoptosis and cell cycle arrest before the G2/M phase (Chowdhury et al. 2017).

Another study examined the in vitro assessment of the elderberry (Sambucus nigra) extract on the motility, viability, and ROS production of bovine spermatozoa. The results showed, that lower concentrations of the elderberry extract ( 5 and $1 \mu \mathrm{g} / \mathrm{ml}$ ) led to an increase in mitochondrial activity in comparison to the control group. The findings of the study indicate that Sambucus nigra extract can possess activitypromoting properties on bovine spermatozoa (Abdramanov et al. 2017).

There is some evidence that phytoestrogens can modulate physiological functions and may exert either a positive or a negative impact on reproductive health 
(Wocławek-Potocka et al. 2013). For example, genistein has been shown to induce the release of estradiol, progesterone and cAMP by the ovaries, maturation of oocyte, as well as the development of zygote in the preimplantation stage (Jefferson and Williams 2011). On the contrary, phytoestrogens present in the green and Indian turmeric has been reported to inhibit proliferation, induce apoptosis and affect steroid hormone release by animal ovarian cells. In addition, isoflavones can change animal sexual development, disrupt the estrous cycle and ovarian functions (Cederroth et al. 2012, Desmawati and Sulastri 2019). Genistein (also present in elderberry extracts used in our study) at high doses $(50-100 \mu \mathrm{M})$ inhibits the growth of human breast cancer cells in vitro, whereas it induces proliferation at lower doses (0.01-10 $\mu \mathrm{M})$, effects that were explained by their estrogenic properties at low doses and cytotoxicity at higher doses (Hsieh et al. 1998). The suppressive effect of rutin on cell viability as reported by a number of previous authors as discussed above, could be attributed to the ability of this phytoestrogen to regulate the release of steroid hormones $17 \beta$-estradiol and progesterone including by the ovarian cells (Sirotkin et al. 2020). In another recent study, Sirotkin et al. (2021) reported a stimulation in $17 \beta$-estradiol, progesterone as well as testosterone production by cultured porcine ovarian granulosa cells by $10 \mu \mathrm{g} . \mathrm{ml}^{-1}$ rutin. However, it was accompanied by a decrease in cell proliferation and apoptosis (Sirotkin et al. 2021). Chlorogenic acid present also in the dominant amount in extracts may play several biological roles. It was showed, that it may affect oocyte maturation and inhibit the progression of meiosis and consequently the entire embryo development in vitro. On the contrary, no effect on the progesterone production by bovine granulosa cells was observed (Nunes et al. 2018). Phytonutrients and herbal supplements such as Sambucus nigra L. extracts might be a natural way to boost steroid hormones during menopause, when female sex hormones drop drastically. Although most studies have focused on the antiviral properties of Sambucus nigra L. particularly owing to the presence of beneficial polyphenolic compounds (Młynarczyk et al. 2018), the potential use of elderflower extract in breast cancer prevention and/or treatment has previously been advocated (Schroder et al. 2016). In the present study we observed, that the secretion of $17 \beta$-estradiol was significantly higher after the addition of higher doses of extracts (elderflower extract at $50 \mu \mathrm{g} \cdot \mathrm{ml}^{-1}$ and elderberry extract at $100 \mu \mathrm{g} \cdot \mathrm{ml}^{-1}$ ). On the other hand, a significant increase in progesterone secretion was observed after addition of a lower dose (12.5 $\left.\mu \mathrm{g} \cdot \mathrm{ml}^{-1}\right)$ of both, elderflower and elderberry extracts. Similarly, Kadasi et al. (2014) reported increased progesterone secretion by granulosa cells after addition of epigallocatechin gallate at a low dose (10 $\mu \mathrm{g} . \mathrm{ml}^{-1}$ EGCG) but not at higher doses. Our study showed, that elderberry can promote steroid hormone release, especially estradiol, which is considered a promoter of ovarian cell proliferation and viability and ovarian folliculogenesis. Therefore, the stimulatory action of black elder extract on healthy ovarian cells may be suggested. Thus, phytocompounds present in Sambucus nigra L. may potentially become effective and less toxic therapeutic agents due to their property of up-regulation of steroid hormones secretion. However, the data obtained from in vitro cell culture system need not fully correspond to the situation in vivo.

In conclusion, black elderberry seems to possess benefits effects on reproductive health. The results of the present study on the effects of elderflower and elderberry extracts on the release of $17 \beta$-estradiol and progesterone indicate towards the involvement of the phytoconstituents of Sambucus nigra L. with ovarian steroidogenesis.

\section{Conflict of Interest}

There is no conflict of interest.

\section{Acknowledgements}

This work was supported by the Ministry of Education, Science, Research and Sport of the Slovak Republic (projects APVV-18-0312, DS-FR-19-0049, VEGA 1/0266/20), The Excellent scientific team "Center of Animal Reproduction (CeRA)", the Operational Programme Integrated Infrastructure within the project: Demand-driven research for the sustainable and innovative food, Drive4SIFood 313011V336, co-financed by the European Regional Development Fund, and AgroBioTech Research Centre built in accordance with the project Building, "AgroBioTech" Research Centre ITMS 26220220180. This work was supported by the Ministry of Education, Youth and Sport of the Czech Republic, project of Multilateral scientific and technological cooperation in the Danube region "Impact of the digestion and absorption processes on the final biological activity of diet phytonutrients: real health added-value" number 8 X20023. 


\section{References}

ABDRAMANOV A, MASSANYI P, SARSEMBAYEVA N, USENBAYEV A, ALIMOV J, TVRDÁ E: The in vitro effect of elderberry (Sambucus nigra) extract on the activity and oxidative profile of bovine spermatozoa. J Microbiol Biotechnol Food Sci 6: 1319-1322, 2017. https://doi.org/10.15414/jmbfs.2017.6.6.1319-1322

AI A, TANG Z, LIU Y, YU S, LI B, HUANG H, WANG X, CAO Y, ZHANG W: Characterization and identification of human immortalized granulosa cells derived from ovarian follicular fluid. Exp Ther Med 18: 2167-2177, 2019. https://doi.org/10.3892/etm.2019.7802

ARNHOLD IJ, LOFRANO-PORTO A, LATRONICO AC: Inactivating mutations of luteinizing hormone beta-subunit or luteinizing hormone receptor cause oligo-amenorrhea and infertility in women. Horm Res 71: 75-82, 2009. https://doi.org/10.1159/000183895

BALDOVSKÁ S, MARUNIAKOVÁ N, SLÁMA P, PAVLÍK A, KOHÚT L, KOLESÁROVÁ A: Efficacy of phytonutrients from pomegranate peel on human ovarian cells in vitro. J Microbiol Biotechnol Food Sci 10: 511-516, 2020. https://doi.org/10.15414/jmbfs.2020.10.3.511-516

BOURAKI G, METALLINOU C, SIMOPOULOU M, CHARALABOPOULOS K, ASIMAKOPOULOS B: Comparison of nine media in the culture of human ovarian granulosa lutein cells. In Vivo 26: 823-825, 2012.

CASTILLO-MALDONADO I, MORENO-ALTAMIRANO MMB, SERRANO-GALLARDO LB: Anti-dengue serotype-2 activity effect of Sambucus nigra leaves-and flowers-derived compounds. Virol Res Rev 1: 1-5, 2017. https://doi.org/10.15761/VRR.1000117

CEDERROTH CR, ZIMMERMANN C, NEF S: Soy, phytoestrogens and their impact on reproductive health. Mol Cell Endocrinol 355: 192-200, 2012. https://doi.org/10.1016/j.mce.2011.05.049

CHEN H, MIAO Q, GENG M, LIU J, HU Y, TIAN L, PAN J, YANG Y: Anti-tumor effect of rutin on human neuroblastoma cell lines through inducing G2/M cell cycle arrest and promoting apoptosis. Sci World J 2013: 269165, 2013. https://doi.org/10.1155/2013/269165

CIOCOIU M, MIRON A, MARES L, TUTUNARU D, POHACI C, GROZA M, BADESCU M: The effects of Sambucus nigra polyphenols on oxidative stress and metabolic disorders in experimental diabetes mellitus. J Physiol Biochem 65: 297-304, 2009. https://doi.org/10.1007/BF03180582

DEROO BJ, KORACH KS: Estrogen receptors and human disease. J Clin Invest 116: 561-570, 2006. https://doi.org/10.1172/JCI27987

CHOWDHURY S, RAY U, CHATTERJEE BP, ROY SS: Targeted apoptosis in ovarian cancer cells through mitochondrial dysfunction in response to Sambucus nigra agglutinin. Cell Death Dis 8: e2762, 2017. https://doi.org/10.1038/cddis.2017.77

DESMAWATI D, SULASTRI D: Phytoestrogens and their health effect. Open Access Maced J Med Sci 7: 495-499, 2019. https://doi.org/10.3889/oamjms.2019.086

DODE MAN, GRAVES CN: Role of estradiol-17ß on nuclear and cytoplasmic maturation of pig oocytes. Anim Reprod Sci 78: 99-110, 2003. https://doi.org/10.1016/S0378-4320(03)00080-0

GABRIELE M, PUCCI L, ÁRVAY J, LONGO V: Anti-inflammatory and antioxidant effect of fermented whole wheat on TNF $\alpha$-stimulated HT-29 and NF-кB signaling pathway activation. J Funct Foods 45: 392-400, 2018. https://doi.org/10.1016/j.jff.2018.04.029

HAGAN CR, FAIVRE EJ, LANGE CA: Scaffolding actions of membrane-associated progesterone receptors. Steroids 74: 568-572, 2009. https://doi.org/10.1016/j.steroids.2008.12.004

HAVELOCK JC, RAINEY WE, CARR BR: Ovarian granulosa cell lines. Mol Cell Endocrinol 228: 67-78, 2004. https://doi.org/10.1016/j.mce.2004.04.018

HSIEH, CY, SANTELL RC, HASLAM, SZ, HELFERICH WG: Estrogenic effects of genistein on the growth of estrogen receptor-positive human breast cancer (MCF-7) cells in vitro and in vivo. Cancer Res 58: 3833-3838, 1998.

JEFFERSON WN, WILLIAMS C: Circulating levels of genistein in the neonate, apart from dose and route, predict future adverse female reproductive outcomes. Reprod Toxicol 31: 272-279, 2011. https://doi.org/10.1016/j.reprotox.2010.10.001 
KADASI A, KOLESAROVA A, MARUNIAKOVA N, GROSSMANN R, STOCHMALOVA A, ALEXA R, SIROTKIN AV: The effect of green tea extract - epigallocatechin gallate (EGCG) on porcine ovarian granulosa cell. J Microbiol Biotechnol Food Sci 3: 107-109, 2014.

KALTSA O, LAKKA A, GRIGORAKIS S, KARAGEORGOU I, BATRA G, BOZINOU E, LALAS S, MAKRIS DP: A green extraction process for polyphenols from elderberry (Sambucus nigra) flowers using deep eutectic solvent and ultrasound-assisted pretreatment. Molecules 25: 921, 2020. https://doi.org/10.3390/molecules25040921

KNUDSEN BF, KAACK KV: A review of human health and disease claims for elderberry (Sambucus nigra) fruit. Acta Hortic 1061: 121-131, 2015. https://doi.org/10.17660/ActaHortic.2015.1061.12

KOLESÁROVÁ A, SIROTKIN AV, MELLEN M, ROYCHOUDHURY S: Possible intracellular regulators of female sexual maturation. Physiol Res 64: 379-386, 2015. https://doi.org/10.33549/physiolres.932838

KOLESAROVA A, ROYCHOUDHURY S, KLINEROVA B, PACKOVA D, MICHALCOVA K, HALENAR M, KOPCEKOVA J, MNAHONCAKOVA E, GALIK B: Dietary bioflavonoid quercetin modulates porcine ovarian granulosa cell functions in vitro. J Environ Sci Health B 54: 533-537, 2019. https://doi.org/10.1080/03601234.2019.1586034

KRAWITZ C, MRAHEIL MA, STEIN M, IMIRZALIOGLU C, DOMANN E, PLESCHKA S, HAIN T: Inhibitory activity of a standardized elderberry liquid extract against clinically-relevant human respiratory bacterial pathogens and influenza A and B viruses. BMC Complement Altern Med 11: 16, 2011. https://doi.org/10.1186/1472-6882-11-16

LECOMTE S, DEMAY F, FERRIERE F, PAKDEL F: Phytochemicals targeting estrogen receptors: Beneficial rather than adverse effects? Int J Mol Sci 18: 1381, 2017. https://doi.org/10.3390/ijms18071381

MAHAJAN DK: Pig model to study dynamics of steroids during ovarian follicular growth and maturation. In: Sourcebook of Models For Biomedical Research. CONN PM (ed.), Humana Press, 2008, pp 425-436. https://doi.org/10.1007/978-1-59745-285-4 45

MAHBOUBI M: Sambucus nigra (black elder) as alternative treatment for cold and flu. Adv Tradit Med 1-10, 2020. https://doi.org/10.1007/s13596-020-00469-Z

MICHALCOVA K, ROYCHOUDHURY S, HALENAR M, TVRDA E, KOVACIKOVA E, VASICEK J, CHRENEK P, BALDOVSKA S, SANISLO L, KREN V, KOLESAROVA A: In vitro response of human ovarian cancer cells to dietary bioflavonoid isoquercitrin. J Environ Sci Health B 54: 752-757, 2019. https://doi.org/10.1080/03601234.2019.1633214

MŁYNARCZYK K, WALKOWIAK-TOMCZAK D, ŁYSIAK GP: Bioactive properties of Sambucus nigra L. as a functional ingredient for food and pharmaceutical industry. J Funct Foods 40: 377-390, 2018. https://doi.org/10.1016/j.jff.2017.11.025

MOTA AH, DUARTE N, SERRA AT, FERREIRA A, BRONZE MR, CUSTÓDIO L, GASPAR MM, SIMOES S, RIJO P, ASCENSAO L, FAÍSCA P, VIANA AS, PINTO R, KUMAR P, ALMEIDA AJ, REIS CP: Further evidence of possible therapeutic uses of Sambucus nigra L. extracts by the assessment of the in vitro and in vivo anti-inflammatory properties of its PLGA and PCL-based nanoformulations. Pharmaceutics 12: 1181, 2020. https://doi.org/10.3390/pharmaceutics12121181

NUNES HP, FURNAS S, DINIS M, BORBA A, DA SILVA JM: Effects of chlorogenic acid on the maturation and fertilisation of bovine oocytes and their embryonic development with a comparative bovine granulosa cell coculture. Anim Reprod (AR) 14: 1057-1061, 2018. https://doi.org/10.21451/1984-3143-AR885

ONISZCZUK A, OLECH M, ONISZCZUK T, WOJTUNIK-KULESZA K, WÓJTOWICZ A: Extraction methods, LC-ESI-MS/MS analysis of phenolic compounds and antiradical properties of functional food enriched with elderberry flowers or fruits. Arab J Chem 12: 4719-4730, 2019. https://doi.org/10.1016/j.arabjc.2016.09.003

PATISAUL HB, JEFFERSON W: The pros and cons of phytoestrogens. Front Neuroendocrinol 31: 400-419, 2010. https://doi.org/10.1016/i.yfrne.2010.03.003

RAINEY WH, SAWETAWAN C, SHAY JW, MICHAEL MD, MATHIS JM, KUTTEH W, BYRD W, CARR BR: Transformation of human granulosa cells with the e6 and e7 regions of human papillomavirus. J Clin Endocrinol Metab 78: 705-710, 1994. https://doi.org/10.1210/jcem.78.3.8126145

MARISA RIBEIRO A, ESTEVINHO BN, ROCHA F: Microencapsulation of polyphenols - The specific case of the microencapsulation of Sambucus Nigra L. extracts - A review. Trends Food Sci Tech 105: 454-467, 2020. https://doi.org/10.1016/j.tifs.2019.03.011 
ROYCHOUDHURY S, HALENAR M, MICHALCOVA K, NATH S, KACANIOVA M, KOLESAROVA A: Green tea extract affects porcine ovarian cell apoptosis. Reprod Biol 18: 94-98, 2018. https://doi.org/10.1016/j.repbio.2018.01.007

SARAVI SSS, SHOKRZADEH M, SHIRAZI FH: Cytotoxicity of Sambucus ebulus on cancer cell lines and protective effects of vitamins $\mathrm{C}$ and $\mathrm{E}$ against its cytotoxicity on normal cell lines. Afr J Biotechnol 12: 3360-3365, 2013. https://doi.org/10.5897/AJB09.1577

SCHRODER L, RICHTER DU, PIECHULLA B, CHROBAK M, KUHN C, SCHULZE S, ABARZUA S, JESCHKE U, WEISSENBACHER T: Effects of phytoestrogen extracts isolated from elder flower on hormone production and receptor expression of trophoblast tumor cells JEG-3 and BeWo, as well as MCF7 breast cancer cells. Nutrients 8: 616, 2016. https://doi.org/10.3390/nu8100616

SIDOR A, GRAMZA-MICHAŁOWSKA A: Advanced research on the antioxidant and health benefit of elderberry (Sambucus nigra) in food - a review. J Funct Foods 18: 941-958, 2015. https://doi.org/10.1016/j.jff.2014.07.012

SIROTKIN A, ZAHORANSKA Z, TARKO A, FABOVA Z, ALWASEL S, HARRATH AH: Plant polyphenols can directly affect ovarian cell functions and modify toluene effects. J Anim Physiol Anim Nutr 105: 80-89, 2020. https://doi.org/10.1111/jpn.13461

SIROTKIN AV, PELLEOVA B, FABOVA Z, MAKOVICKY P, ALWASEL S, HARRATH AH: Rutin directly affects stimulatory action of FSH on the ovarian cell. Pharma Nutrition 15: 100247, 2021. https://doi.org/10.1016/j.phanu.2020.100247

WOCŁAWEK-POTOCKA I, MANNELLI C, BORUSZEWSKA D, KOWALCZYK-ZIEBA I, WAŚNIEWSKI T, SKARŻYŃSKI DJ: Diverse effects of phytoestrogens on the reproductive performance: Cow as a model. Int J Endocrinol 2013: 650984, 2013. https://doi.org/10.1155/2013/650984 